\title{
Evaluasi Penyuluhan Pemeliharaan Itik Lokal Jantan Berbasis Metode Inditik Terhadap Tingkat Pengetahuan dan Sikap Petani di Desa Gaum, Kecamatan Tasikmadu, Kabupaten Karanganyar
}

\author{
R. Indreswari, A. Ratriyanto dan R. Dewanti \\ Program Studi Peternakan, Fakultas Pertanian, Universitas Sebelas Maret \\ Jl. Ir. Sutami 36A, Surakarta 57126 \\ Email: rysca1103@uns.ac.id
}

\begin{abstract}
ABSTRAK
Penelitian ini bertujuan untuk mengevaluasi hasil penyuluhan model pemeliharaan itik lokal jantan berbasis metode intensifikasi padi dan itik (Inditik) pada Kelompok Tani Sabar Subur Dusun Kwarasan, Desa Gaum, Kecamatan Tasikmadu, Kabupaten Karanganyar. Metode yang digunakan untuk mengumpulkan data adalah dengan menggunakan kuesioner. Data pretest dan posttest diolah dengan Uji Wilcoxon untuk mengetahui apakah ada perbedaan tingkat pengetahuan dan sikap sebelum dan sesudah diberi penyuluhan. Hasil analisis menunjukkan bahwa penyuluhan cukup efektif dalam meningkatkan pengetahuan petani dalam hal pemahaman terhadap manajemen pemeliharaan itik berbasis metode inditik.
\end{abstract}

Kata kunci: Inditik, pemeliharaan, itik lokal jantan, penyuluhan

\section{Evaluation of Extension in Male Local Ducks Maintenance Based Duck and Rice Intensification Method on the Level of Knowledge and Attitude of Farmers}

\begin{abstract}
The aimed of this study was to evaluate the results of extension in local ducks maintenance based on duck and rice intensification method at Farmers Group Sabar Subur Kwarasan, Gaum, Tasikmadu, Karanganyar. The data was collected by using questionnaires. Pretest and posttest data were analyzed by the Wilcoxon test to determine the differences in the level of knowledge and attitudes before and after extension. The results showed that extension quite effective in improving farmers' knowledge in terms of understanding the duckling maintenance management based duck and rice intensification method.
\end{abstract}

Keywords: duck and rice intensification method, maintenance, male local ducks, extension

\section{PENDAHULUAN}

Itik merupakan jenis ternak unggas yang umum dipelihara di Indonesia untuk menghasilkan telur. Masyarakat sudah terbiasa mengonsumsi telur itik. Namun, daging itik belum banyak dikonsumsi. Hal ini dikarenakan daging itik yang dijual umumnya berasal dari itik afkir. Anak itik jantan belum banyak dimanfaatkan. Selain harganya murah, pertumbuhannya juga relatif lebih cepat daripada anak itik betina 
atau ayam sehingga bisa dimanfaatkan sebagai penghasil daging (Mahfudz et al., 2001).

Sebagai unggas air, itik cocok dikembangkan di agroekosistem sawah (Guntoro, 2011). Teknologi intensifikasi padi dengan itik (Inditik) adalah suatu sistem mix farming yang merupakan suatu terobosan intensifikasi padi dengan menggunakan ternak itik. Ternak itik difungsikan sebagai fertilizer, pestisider, herbisider dan tenaga untuk menyiangi padi. Di lain pihak ternak itik mendapatkan area umbaran. Dewasa ini area umbaran semakin sempit karena beralihnya fungsi tanah pertanian. Hasil penelitian Mahfudz et al. (2001) menyatakan teknologi Inditik dapat menekan pakan itik sampai $50 \%$ dan produksi padi dapat meningkat $35 \%$ dibanding intensifikasi padi biasa. Teknologi Inditik selain menekan biaya produksi dan meningkatkan hasil juga meningkatkan efisiensi, karena pada lahan yang sama dan dalam waktu yang bersamaan dapat diproduksi dua komoditas sekaligus yaitu padi dan itik. Produknya merupakan bahan pangan organik yang sangat aman dan sehat, karena tidak menggunakan pupuk buatan, pestisida, dan herbisida. Selain itu juga menghemat tenaga menyiangi padi yang akhir-akhir ini semakin langka.

Para petani di Dusun Kwarasan, Desa Gaum, Kecamatan Tasikmadu bergabung dalam sebuah kelompok tani yang bernama Sabar Subur. Kegiatan rutin kelompok tani berhubungan dengan pengelolaan pertanian tetapi sistem pertanian yang dikelola masih konvensional. Selain itu banyak petani bermodal kecil yang berharap banyak kepada bantuan pemerintah. Ketersediaan lahan yang masih luas serta berbagai komoditas pertanian yang ada belum mampu dimanfaatkan oleh kelompok tani sebagai sumber ekonomi yang produktif. Oleh karena itu diperlukan kegiatan penyuluhan untuk memberikan informasi yang berguna bagi masyarakat (dimensi komunikatif) dan kemudian membantu masyarakat untuk mendapatkan pengetahuan, ketrampilan dan sikap yang diperlukan untuk menggunakan informasi dan teknologi secara efektif (dimensi pendidikan) (Leeuwis, 2009). Untuk itu, diperlukan strategi penyuluhan yang tepat agar peserta penyuluhan secara aktif mengikuti kegiatan penyuluhan, sehingga mampu meningkatkan penerimaan dan pengetahuan mereka. Dikaitkan dengan upaya pemberdayaan petani, pengetahuan ini pada akhirnya akan memengaruhi perilaku dalam pengelolaan usahatani ke arah yang lebih baik. Penelitian ini bertujuan untuk mengevaluasi hasil penyuluhan model pemeliharaan itik lokal jantan berbasis metode intensifikasi padi dan itik (Inditik).

\section{MATERI DAN METODE}

Materi yang digunakan adalah lima belas anggota kelompok tani "Sabar Subur" Dusun Kwarasan, Desa Gaum, Kecamatan Tasikmadu, Karanganyar. Dalam penelitian ini semua anggota kelompok tani dijadikan sebagai sampel, karena jumlah anggota kurang dari 30, sehingga disebut sampel jenuh (Sugiyono, 2005). Sampel lokasi penelitian ditentukan secara purposive menurut Arikunto (2010). Pemilihan lokasi didasarkan pada tingkat pengetahuan anggota tentang materi pemeliharaan itik berbasis Inditik yang masih relatif rendah. Hal ini dikarenakan belum pernah dilakukan penyuluhan dengan materi tersebut.

Responden diberi pretest untuk menentukan pengetahuan dan sikap responden sebelum diberi penyuluhan. Kemudian responden diberi materi penyuluhan tentang manajemen pemeliharaan itik berbasis metode Inditik. Penyuluhan diberikan dengan media power point. Setelah itu responden diberi posttest untuk menentukan pengetahuan dan sikap mereka setelah menerima materi 
penyuluhan. Alokasi waktu penelitian ini ialah sebagai berikut : 1) 15 menit pertama digunakan untuk memberikan penjelasan tentang berbagai hal yang berhubungan dengan penelitian; 2) 20 menit untuk pretest; 3) 60 menit untuk menyampaikan materi penyuluhan dan diskusi dan 4) 20 menit untuk posttest. Peningkatan pengetahuan dan sikap diukur dengan membandingkan nilai pretest dan posttest dengan uji Wilcoxon. Pertanyaan untuk mengukur nilai pengetahuan dan sikap berbentuk soal obyektif telah diuji validitas dan reliabilitasnya (Morissan, 2012), terdiri dari sebanyak 20 soal untuk pengetahuan dan sebanyak 10 soal sikap. Aspek pengetahuan yang diukur meliputi bibit, perkandangan, pakan, penyakit dan Inditik. Pertanyaan mengenai sikap diuraikan untuk mengetahui pola pikir petani dalam mengadopsi model pemeliharaan Inditik sehingga dapat meningkatkan produktivitas ternak dan pendapatan.

Hasil pretest dan posttest dianalisis secara deskriptif dalam bentuk tabulasi. Perbedaan nilai pretest dan posttest merupakan perubahan tingkat pengetahuan dan sikap. Untuk mengetahui peningkatan pengetahuan dan sikap digunakan kriteria persentase efektivitas dengan rumus $=((\mathrm{PS}-$ $\mathrm{PR}) /(\mathrm{N} 2 \mathrm{Q}-\mathrm{PR})) \times 100 \%$, dimana $\mathrm{PS}=$ posttest, $\mathrm{PR}=$ pretest, $\mathrm{N}=$ jumlah responden, $2=$ nilai tertinggi, $\mathrm{Q}=$ jumlah pertanyaan, $100 \%=$ pengetahuan yang ingin dicapai. PSPR merupakan peningkatan pengetahuan dan N2Q-PR merupakan nilai kesenjangan. Persentase efektivitas tingkat pengetahuan dibagi atas tiga kriteria (Ginting, 1991) yaitu: kurang efektif $(<32 \%)$, cukup efektif $(\geq 32-64 \%)$ dan efektif $(\geq 64 \%)$.

\section{HASIL DAN PEMBAHASAN}

\section{Pengetahuan Petani}

Berdasarkan uji Wilcoxon terdapat perbedaan antara nilai pretest dan posttest.
Kegiatan penyuluhan cukup efektif meningkatkan pengetahuan petani dengan efektivitas penyuluhan sebesar $51,25 \%$ (Tabel 1). Menurut Sudarta (2002) pengetahuan petani sangat membantu dan menunjang kemampuan untuk mengadopsi teknologi dalam usahatani dan kelanggengan usaha taninya. Semakin tinggi tingkat pengetahuan petani maka kemampuan dalam mengadopsi teknologi di bidang pertanian juga tinggi, demikian pula sebaliknya.

Hasil uji Wilcoxon menyatakan terdapat perbedaan yang nyata antara skor pretest dan posttest pada pengetahuan petani di bidang seleksi bibit, perkandangan, pakan, penyakit dan model pemeliharaan inditik (Tabel 2). Penyuluhan cukup efektif meningkatkan pengetahuan petani pada bidang-bidang tersebut. Peningkatan pengetahuan merupakan salah satu indikasi efektifnya penyuluhan yang dilakukan (Kartasaputra 1991).

Menurut Kartasaputra efektivitas penyuluhan dapat mencapai efisiensi dalam mewujudkan perubahanperubahan pada sikap dan tingkat pengetahuan bagi peserta penyuluhan agar menjadi lebih baik dari sebelumnya. Efektivitas penyuluhan yang telah dilakukan didukung oleh beberapa faktor, antara lain metode penyuluhan, media penyuluhan, materi penyuluhan serta tempat dan waktu penyuluhan (Setiana, 2005).

Metode penyuluhan yang digunakan adalah metode berdasarkan pendekatan massal yang dapat menjangkau sasaran dengan jumlah yang cukup banyak. Metode ini sangat efektif digunakan dalam menimbulkan keingintahuan dan kesadaran peserta penyuluhan terhadap materi yang disampaikan. Media LCD digunakan dalam membantu memperjelas materi yang disampaikan pada peserta penyuluhan. Materi yang disampaikan disesuaikan dengan tingkat pengetahuan peserta 
Tabel 1. Evaluasi hasil penyuluhan

\begin{tabular}{lccc}
\hline \hline & Nilai Pretest & Nilai Posttest & Efektivitas Penyuluhan (\%) \\
\hline Pengetahuan & 67 & 354 & 51,25 \\
Sikap & 271 & 274 & 1,43 \\
\hline
\end{tabular}

Tabel 2. Evaluasi hasil penyuluhan berdasarkan materi penyuluhan

\begin{tabular}{lcc}
\hline \multicolumn{1}{c}{ Materi Penyuluhan } & Efektivitas Penyuluhan $(\%)$ & Pretest-Posttest \\
\hline Bibit & 53,57 & Berbeda nyata \\
Perkandangan & 48,81 & Berbeda nyata \\
Pakan & 44,64 & Berbeda nyata \\
Penyakit & 54,46 & Berbeda nyata \\
Inditik & 53,57 & Berbeda nyata \\
\hline
\end{tabular}

Tabel 3. Pendapat responden terhadap sikapnya dalam melakukan model pemeliharaan berbasis Metode Inditik

\begin{tabular}{lrr}
\hline \multirow{2}{*}{ Klasifikasi } & \multicolumn{2}{c}{ Persentase (\%) } \\
\cline { 2 - 3 } & Pretest & Posttest \\
\hline Negatif & 1,43 & 0,00 \\
Netral & 3,57 & 3,57 \\
Positif & 95,00 & 96,43 \\
\hline Jumlah & 100,00 & 100,00 \\
\hline
\end{tabular}

penyuluhan sehingga mudah dipahami dan diaplikasikan sesuai tingkat pendidikan responden. Selain itu, efektivitas penyuluhan juga disebabkan adanya kesesuaian materi dengan kebutuhan peserta. Menurut Umstot (1988), kebutuhan akan memotivasi seseorang untuk berperilaku ke arah pemenuhan kebutuhan tersebut. Semua faktor tersebut mendukung terwujudnya efektivitas penyuluhan yang dilakukan. Hal ini terlihat dengan jelas pada terjadinya peningkatan pengetahuan responden setelah mengikuti penyuluhan dibandingkan sebelum mengikuti penyuluhan.

Penyuluhan budidaya ternak itik dapat diterima oleh peserta karena : (1) didasarkan pada analisis sistuasi yang sesuai dengan kondisi masyarakat setempat, (2) berlandaskan pada kebutuhan untuk mengembangkan ternak itik serta (3) menunjukkan tujuan, solusi permasalahan dan manfaat bagi peternak (Martinez dalam Valera et al., 1987). Selain itu, dari aspek inovasi, pesan penyuluhan juga mampu meningkatkan penerimaan peserta terhadap pesan, karena atribut inovasi berupa relative advantage, compatibility, complexity, triability dan observability memenuhi atribut inovasi yang baik (Rogers, 2003). Atribut inovasi tersebut diantaranya adalah: (1) beternak itik memberi keuntungan baik dari peningkatan sisi pendapatan maupun pemenuhan gizi keluarga; (2) sesuai dengan ketersediaan sumberdaya tenaga kerja, alam dan lingkungan pedesaan; (3) beternak itik relatif sederhana dan mudah dipelajari serta diaplikasikan; (4) mudah dicoba dalam skala rumah tangga dan (5) hasilnya mudah diamati.

\section{Sikap Petani \\ Penyuluhan kurang efektif} memengaruhi sikap petani dengan efektivitas 
penyuluhan sebesar 1,07\% (Tabel 1). Adanya penyuluhan tidak memengaruhi secara nyata sikap petani untuk mau beternak itik dengan metode inditik. Petani sejak awal sebelum penyuluhan sudah mempunyai antusiasme yang tinggi dalam program ini, hal ini dapat dibuktikan nilai pretest pada penilaian sikap sudah sangat tinggi. Sikap positif petani mengapresiasi model pemeliharaan Inditik pada awal program sudah sangat baik (Tabel 3).

\section{SIMPULAN}

Simpulan dari penelitian ini adalah penyuluhan cukup efektif dalam meningkatkan pengetahuan petani dalam hal pemahaman terhadap manajemen pemeliharaan itik berbasis metode Inditik. Penyuluhan tidak cukup efektif memengaruhi sikap petani dikarenakan pada awal program sudah mengapresiasi program Inditik dengan sangat baik.

\section{DAFTAR PUSTAKA}

Arikunto, S. 2010. Prosedur Penelitian Suatu Pendekatan Praktek. Rineka Cipta, Jakarta.

Ginting, E. 1991. Metode Kuliah Kerja Lapang. Universitas Brawijaya, Malang.
Guntoro, S. Saatnya Menerapkan Pertanian Tekno-Ekologis, Sebuah Model Pertanian Masa Depan untuk Menyikapi Perubahan Iklim. AgroMedia Pustaka. Jakarta.

Kartasaputra, A.G. 1991. Teknologi Penyuluhan Pertanian. Bumi Aksara, Jakarta.

Leeuwis, C. 2009. Komunikasi Untuk Inovasi Pedesaan. Diterjemahkan oleh B. E. Sumarah. Kanisius, Yogyakarta.

Mahfudz, L.D., U. Atmomarsono, W. Sarengat dan N.S. Yuningsih. 2001. Pengaruh luas lahan pada sistem intensifikasi padi dengan itik (Inditik) terhadap performance itik lokal jantan. Animal Production. Edisi Khusus: 6-12.

Morissan, M.A., 2012. Metode Penelitian Survei. Kencana Prenada Media Group, Jakarta.

Rogers, E. M., 2003. Diffusion of Innovations. Fifth Edition. Free Press. New York.

Sudarta, W. 2002. Pengetahuan dan Sikap Petani Terhadap Pengendalian Hama Terpadu. Jurnal Sosial Ekonomi Pertanian dan Agribisnis. SOCA. 2: $31-34$.

Sugiyono.2005. Statistika untuk Penelitian. Alfabeta, Bandung.

Umstot, D. D. 1988. Understanding Organizational Bahavior. West Publishing Company. New York.

Valera, J. B, V.A. Martines and R. F. Plopino, 1987. An Introduction to Extension Delivery Systems. Island Publishing House, Inc. Manila. 